\title{
Changes in Biochemical and Physico-chemical Qualities during Drying of Pulp Preconditioned and Fermented Cocoa (Theobroma cacao) Beans
}

\author{
Emmanuel Ohene Afoakwa ${ }^{1 *}$, Agnes Simpson Budu ${ }^{1}$, Henry Mensah-Brown ${ }^{2}$, Jemmy Felix \\ Takrama $^{3}$ and Evans Akomanyi ${ }^{1}$ \\ ${ }^{1}$ Department of Nutrition \& Food Science, University of Ghana, Legon-Accra, Ghana \\ ${ }^{2}$ Department of Food Process Engineering, University of Ghana, Legon-Accra, Ghana \\ ${ }^{3}$ Cocoa Research Institute of Ghana, New Tafo Akim Eastern Region, Ghana
}

Received: November 23, 2013; Accepted: April 25, 2014; Published: April 28, 2014

*Corresponding author: Emmanuel Ohene Afoakwa, Department of Nutrition \& Food Science, University of Ghana, P. O. Box LG 134 Legon-Accra, Ghana, Tel: +233(0)244-685893/+233-203505696; E-mail: eoafoakwa@gmail.com; eafoakwa@ug.edu.gh

\begin{abstract}
This study investigated the effects of post-harvest pod storage as a means of pulp preconditioning on the souring production, flavour precursors development and free fatty acids during drying of fermented Ghanaian cocoa beans. A 4 x 4 full factorial experiment was conducted with pod storage $(0,7,14,21$ days $)$ and drying times $(0,2,4$ and 6 days $)$ as the principal factors. The souring/acidification indices ( $\mathrm{pH}$ and titratable acidity), total sugar, total nitrogen and free fatty acids (FFA) were studied using standard analytical methods. The results showed that titratable acidity, total sugars and total nitrogen in cocoa beans decreased during drying and with increasing pod storage durations probably due to their participation in Maillard nonenzymatic reactions to form flavour volatiles and colour pigments as Amadori intermediates. By contrast, FFAs and $\mathrm{pH}$ increased during drying and with increasing pod storage durations. Pod storage for up to 7 days followed by 6 days of fermentation and drying respectively produced beans with acceptable FFA values below $1.75 \%$ whilst enhancing the flavour precursors development and reductions in nib acidity. However, these observed changes were more dependent on pod storage than on drying.
\end{abstract}

Keywords: Cocoa; Theobroma cacao; Pod storage; Pulp preconditioning; Fermentation; Flavour volatiles

\section{Introduction}

Theobroma cacao belongs to the family Sterculiaceae, with three main varieties - Criollo, Forastero and Trinitario dominating the world cocoa trade. Cocoa is grown principally in West Africa, Central and South America and South-East Asia, and the eight largest producing countries include Côte d'Ivoire, Ghana, Indonesia, Nigeria, Brazil, Cameroon, Ecuador and Malaysia. Typically, the Forastero variety is grown across the West African countries - Cote d'Ivoire, Ghana, Nigeria and Cameroon and accounts for $\sim 70 \%$ of the beans sold on the global cocoa market [1-3].

Chocolate flavour originates from flavour precursors generated in cocoa beans during fermentation and drying and are transformed into flavour notes during roasting. The fermentation process triggers an array of chemical reactions within the bean which generate the biochemical precursors of chocolate flavour, aroma and colour [1,4-8]. The process produces alcohol and acids, and generates heat, typically raising the temperature of the fermenting beans to about $45^{\circ} \mathrm{C}$ to $50^{\circ} \mathrm{C}$ within the first 72 hours. The acids lower the $\mathrm{pH}$ and cause acidification or souring of the bean which is a desirable quality in chocolate. The acid and heat generated kills the cocoa bean causing the cell walls within the bean to break down, allowing enzymes to come into contact with their substrates resulting in the beginning of the biochemical changes in the bean [9-11].

During fermentation, bitter and astringent flavours which are due to polyhydroxyphenols such as catechins, flavan-3ols, anthocyanins, and proanthocyanadins are modified in a multi-step process, oxidised and condensed enzymatically into milder tasting substances. Anthocyanins are converted into anthocyanidin by glucosidase enzymes. Anthocyanidin are oxidized by polyphenol oxidase into quinone which combines with amino acids and proteins to form melanin. Polyphenols diffuse out of the bean during the fermentation and are also oxidised by polyphenol oxidases to produce mostly insoluble tannins. The enzymic reactions continue in several ways and yield flavour precursors and some flavour notes [10,12-14]. The great majority of chocolate flavour compounds are formed due to biochemical and enzymatic reactions that occur within the cotyledon [8,10,15-18].

Pulp preconditioning entails changing the properties of the pulp in cocoa beans prior to fermentation and since the pulp is the substrate metabolised during fermentation, changes in the pulp affect the production of acids by lactic acid bacteria, yeasts and acetic acid bacteria $[15,19]$. The technique reduces the formation of acids throughout the fermentation without enhancing the degradation of acids at the end of fermentation. 
Methods of pulp preconditioning include, bean spreading, bean pressing, depulping and post harvest pod storage [19].

Pod storage as a method of pulp preconditioning involves keeping the harvested pod (fruit) for a period of time before breaking the pod. In West Africa, the pods are usually left on the ground to be gathered together for breaking by a team of workers after a few days of harvesting. Ghanaian farmers unknowingly adopted this technique of pod storage simply by their practice of using family labour to collect the harvested pods into piles before the pods are opened to remove the beans for fermentation. During pod storage, the beans within the pod lose moisture which allows more air to penetrate the pods into beans before the pods are broken to start the fermentation. This facilitates the fermentation process with accompanied faster temperature rises and thus resulting in improved quality of the cocoa beans $[15,19,20]$. Previous research findings revealed that fermentation of beans from stored pods are more rapid and result in higher brown bean counts [21]. As well, pod storage has been reported to reduce pulp volume and acidity, effecting subsequent reductions in the polyphenolic and anthocyanin components, resulting in enhanced bean flavour quality $[3,16]$.

Drying is initiated when the fermentation process is complete and this reduces the moisture content of the beans from ca. $60 \%$ to ca. $7.0 \%$ an appropriate moisture content that provides security for the prolonged storage of the beans [5,22]. Above $8 \%$ moisture there is the danger of moulds developing within the beans, whilst below $5 \%$ the beans are very brittle [1]. Drying also allows some of the chemical changes which occur during fermentation to continue and improve flavour development. This helps to reduce bitterness and astringency and also the development of the chocolate brown colour of well fermented cocoa beans $[13,23]$.

Even though some studies have been conducted on pulp pre-conditioning and its effects on the quality of cocoa beans, previous work have been focussed on elucidating the effects on acidification, biochemical constituents (mainly flavour precursors) and polyphenolic constituents during fermentation $[3,11,14,18-20]$. Knowledge on the further changes in acidification, sugar and protein nitrogen (flavour precursors) concentrations and free fatty acids during drying largely remains unknown. Thus, the objective of this work was to investigate changes in biochemical qualities (flavour precursors development and free fatty acids) and physico-chemical qualities (souring production by acidification) during drying of pulp pre-conditioned and fermented cocoa beans.

\section{Materials and Methods}

\section{Materials}

Fleshly harvested pods of mixed hybrids (Amelonado and Amazonica) were obtained from the cocoa plantation of the Cocoa Research Institute of Ghana (CRIG), Akim Tafo in the Eastern Region of Ghana and used for the study.

Sample preparation: Freshly harvested cocoa pods (fruits) were first sorted out (only healthy pods were picked) and kept in a heap for four different storage duration $(0,7,14$ and 21 days).
Each heap for the four storage periods was made up of 600 pods. The pods were stored under shade and were broken after the specified days of storage. The beans were fermented for six days using the heap fermentation technique. The fermenting cocoa beans were mixed after every 48 hours until the fermentation process was over. The fermented cocoa beans were dried in the open sun on raised platforms using the traditional process [2]. Drying started 8 am and ended at 5 pm each day for six days. The beans were stirred four times each day and were covered with palm mats in the evening till the next morning. Samples for analyses were taken immediately after fermentation (prior to drying) and after every 48 hours of drying intervals. The samples taken were packaged in air tight plastic bags and taken immediately to the laboratory for analysis. The sample treatments were conducted in duplicates.

Experimental Design: The studies were conducted using a 4 $\mathrm{x} 4$ full factorial design with experimental factors as pod storage $(0,7,14$ and 21 days) and and drying times $(0,2,4$ and 6 days). Changes in moisture content, $\mathrm{pH}$, non-volatile (titratable) acidity, total sugars, protein nitrogen and free fatty acids were studied.

\section{Methods}

Moisture determination: The moisture content of the beans (nib) was determined using the International Organisation for Standards (ISO) method as modified by Hamid and Lopez (2000). Approximately $10 \mathrm{~g}$ of ground bean sample was placed into a preweighed dish $\left(\mathrm{W}_{1}\right)$ with a lid and re-weighed to the nearest $\mathrm{mg}$ $\left(\mathrm{W}_{2}\right)$. Dishes and contents were put in an oven at $103 \pm 2^{\circ} \mathrm{C}$ for 16 hours. The results were calculated and the mean values reported.

Determination of $\mathrm{pH}$ and non-volatile (titratable) acidity: Non-volatile acidity of the cocoa beans were determined according to AOAC method 970.21, [24] (AOAC, 2005) and expressed as \% acetic acid by titrating juice with $0.1 \mathrm{~N} \mathrm{NaOH}$. Five grams samples of the beans were homogenized for $30 \mathrm{~s}$ in $100 \mathrm{ml}$ of hot distilled water and vacuum filtered through Whatman filter paper No. 4. A $25 \mathrm{ml}$ aliquot was pipetted into a beaker and the $\mathrm{pH}$ measured using a pH meter (model MP230 Mettler Toledo MP 230, Geneva, Switzerland). A further $25 \mathrm{ml}$ aliquot was titrated to an end point $\mathrm{pH}$ of 8.1 with $0.01 \mathrm{~N} \mathrm{NaOH}$ and the values reported as moles of sodium hydroxide per $100 \mathrm{~g}$ dry nibs. The results were calculated and the mean values reported.

Determination of total sugars: Total sugars were determined using the phenol sulphuric acid method 9 [25]. Dry weights of the samples were determined by drying the fresh samples overnight in an oven at $105^{\circ} \mathrm{C}$. The sample was boiled in $80 \%$ ethanol under reflux for 30-40 min and the supernatant removed. The ethanol was evaporated under reduced pressure in a rotary evaporator. Some water was added to make sure the sugar present was in solution. After removal of the alcohol, alcohol-soluble, water-insoluble substances were precipitated. The precipitate was filtered into a clean flask through Whatman No. 41 filter paper followed by washing of the paper with distilled water. The extract was clarified by adding $5 \mathrm{ml}$ of the $\mathrm{ZnSO}_{4}$ solution to the extract followed by $4.94 \mathrm{ml}$ of the $\mathrm{Ba}(\mathrm{OH})_{2}$ solution. The solution was allowed to stand for about $5 \mathrm{~min}$. and 
filtered through Whatman No 41; the filter paper was washed with distilled water to remove any sugar still trapped in the precipitate. A mixture of Zeokarb $225\left(\mathrm{H}^{+}\right)$, a cation exchange resin, and Deacidite FF (OH) was added to the filtrate, shaken and then filtered. To $1 \mathrm{ml}$ of the extract, $1 \mathrm{ml}$ phenol reagent and $5 \mathrm{ml}$ of $\mathrm{H}_{2} \mathrm{SO}_{4}$ was added and allowed to stand for an hour to develop colour. The absorbance of the sample was read at $480 \mathrm{~nm}$ and the results calculated. The analysis was conducted in triplicates and the mean values reported.

Determination of protein: Protein content of the nibs was determined by the Kjeldahl method using the [24] AOAC (2005) method 970.22. The percent protein was calculated by multiplying the percent nitrogen by the conversion factor 6.25 . The analysis was conducted in triplicates and the mean values are reported.

Determination of free fatty acids (FFA): Fat from the samples was extracted with petroleum ether $\left(40-60^{\circ} \mathrm{C}\right)$ in a Soxhlet apparatus using [24] AOAC (2005) method 963.15. Free fatty acid of the oils extracted was determined using [26] IOCCC method 42-1993, (IOCCC, 1996). Five (5) gram of the oil was weighed into a dry $250 \mathrm{ml}$ stopper conical flask and $25 \mathrm{ml}$ of 95\% Ethanol/Ether (1:1) and phenolphthalein indicator. The solution was titrated with $0.1 \mathrm{~N} \mathrm{NaOH}$, shaking constantly until pink colour persisted for 30 seconds and the percentage free fatty acid determined. The analysis was conducted in triplicates and the mean values reported.

\section{Statistical analysis}

The data were analysed using Statgraphics software version 3.0 (STSC Inc, Rockville, MD, USA) for analysis of variance (ANOVA). Least significant difference (LSD) was used to separate and compare the means and significance was accepted at $5 \%$ level $(p<0.05)$. Further analyses were conducted to evaluate the combined effect of pulp preconditioning and drying time on the studied parameters using response surface methodology. The data obtained were evaluated using stepwise multiple regression procedures. Models were developed to relate pulp preconditioning and drying time on the moisture content, souring production (non-volatile acid and $\mathrm{pH}$ ), protein nitrogen, total sugars and free fatty acids in cocoa beans. The coefficients of the variables in the models and their contribution to the model's variation were reported. The $\mathrm{R}^{2}$ values were used to judge the adequacy of the models. The $\mathrm{R}^{2}$ of a model refers to the proportion of variation in the response attributed to the model rather than random error. For a good fit of a model, an $\mathrm{R}^{2}$ of at least $60 \%$ was used. All sample treatments were conducted in duplicates, the analyses in triplicates and the mean values reported.

\section{Results and Discussion}

\section{Effect of drying time and pod storage time on ph of cocoa nibs}

The $\mathrm{pH}$ of cocoa beans is a very important physico-chemical property as it indicates the level of souring production or acidification of the bean after fermentation. High $\mathrm{pH}$ indicates low acidification and vice versa. The level of $\mathrm{pH}$ also determines the fermentation status, biochemical reactions and tastes of the bean. For instance, beans with low $\mathrm{pH}$ tastes acidic and beans with high pH above 7 are likely to have been over-fermented [1,2,9,10,27].

The data obtained for the changes in $\mathrm{pH}$ during drying of pulp pre conditioning of cocoa beans was fitted into a multiple regression model as follows;

$\mathrm{Z}=5.29095+0.15462 \mathrm{X}_{1}+0.06441 \mathrm{X}_{2}-0.00290 \mathrm{X}_{1}^{2}-0.00234 \mathrm{X}_{2}^{2}$ $+0.00126 \mathrm{X}_{1}{ }^{*} \mathrm{X}_{2}$ with $\mathrm{R}^{2}=96.9 \%$. Where $\mathrm{Z}=\mathrm{pH}, \mathrm{X}_{1}=$ pod storage time, $\mathrm{X}_{2}=$ drying time

The initial pH of the fresh non pod stored beans after fermentation was 5.14. After six days of drying the $\mathrm{pH}$ increased slightly to 5.69. The initial $\mathrm{pH}$ of the 7,14 and 21days pod stored beans after fermentation was 6.50, 6.83 and 7.13 respectively. The result as represented in Figure 1 indicates that, $\mathrm{pH}$ increased as drying time increased. These increases in $\mathrm{pH}$ were however very slight and non-significant (Table 1). The increases in $\mathrm{pH}$ during drying might be due to the fact that some of the volatile organic acids mainly acetic acids might have been lost along with the evaporating moisture from the beans [1].

The significant $(\mathrm{p}<0.001)$ increases in $\mathrm{pH}$ of pod stored beans after fermentation is suspected to be due to the reduction in pulp volume during pod storage suppresses the anaerobic phase of fermentation and under these conditions the development of lactic acid bacteria is suppressed and the respiration of sugars by yeasts is considerably increased over alcoholic fermentation and therefore nib pH value does not fall below $5.0[16,19]$ During fermentation (with non pod stored beans) the sticky pulp causes anaerobic conditions and ethanol fermentation to predominate as long as sugars are available during the first hours of fermentation $[1,9]$.

The response surface plots developed (Figure 1) showed a curvilinear nature of the effect of pod storage time on $\mathrm{pH}$, meaning that as pod storage durations increased $\mathrm{pH}$ increased drastically. The significant increases in $\mathrm{pH}$ during pod storage and drying is a very important phenomenon as it produces the desired sourness in the fermented beans and also has great influence on Maillard non-enzymatic browning, and flavour development during subsequent processing [13].

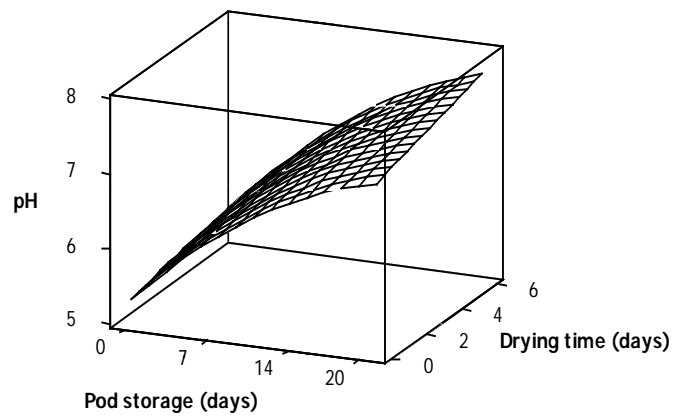

Figure 1: Response surface plot of effect of drying time and pod storage on $\mathrm{pH}$ of cocoa nibs. 
Table 1: F-values from ANOVA for the changes in biochemical and physico-chemical constituents of pod stored beans during drying.

\begin{tabular}{|c|c|c|c|c|c|c|}
\hline \multirow[b]{2}{*}{ Variables } & \multicolumn{6}{|c|}{ F-values } \\
\hline & Moisture & pH & Titratable acidity & Total sugars & Protein & FFA \\
\hline Constant & $22.989 *$ & $37.500^{*}$ & $32.741^{*}$ & $21.757^{*}$ & $45.948^{*}$ & $7.166^{*}$ \\
\hline$X_{1}$ & $-3.587^{*}$ & 7.177* & $-14.884^{*}$ & $-2.154^{*}$ & $-6.665^{*}$ & 1.399 \\
\hline $\mathrm{X}_{2}$ & $-8.655^{*}$ & 0.854 & $-2.896^{*}$ & $-4.387 *$ & $-13.135^{*}$ & -0.035 \\
\hline $\mathrm{X}_{1}^{2}$ & -0.655 & $-3.154^{*}$ & $7.554^{*}$ & -0.312 & 0.466 & 0.039 \\
\hline $\mathrm{X}_{2}^{2}$ & $2.912^{*}$ & -0.208 & 0.814 & 1.036 & $5.767^{*}$ & 0.954 \\
\hline $\mathrm{X}_{1}^{*} \mathrm{X}_{2}$ & $4.826^{*}$ & 0.492 & 1.306 & 1.136 & 6.698* & 1.888 \\
\hline $\mathrm{R}^{2}$ & 0.974 & 0.969 & 0.989 & 0.950 & 0.986 & 0.907 \\
\hline
\end{tabular}

* Significant at $\mathrm{p} \leq 0.05$

\section{Effect of drying time and pod storage time on titratable acidity of cocoa nibs}

Volatile acidity formed during cocoa beans fermentation reaches approximately $2 \%$ of the dry basis. This acidity is the result of some components such as acetic, propionic, butyric, isobutyric and isovaleric acids but $90 \%$ of these components are acetic acid, which has an important role in souring production or acidification as well as the catalysis of enzymatic reactions for production of components of desirable sensorial characteristics in the fermented beans $[13,23]$.

The data obtained for the changes in titratable acidity during drying of the pulp preconditioned cocoa beans was fitted into a multiple regression model as follows:

$\mathrm{Z}=1.38080-0.09584 \mathrm{X}_{1}-0.06526 \mathrm{X}_{2}+0.00207 \mathrm{X}_{1}^{2}+0.00273 \mathrm{X}_{2}^{2}$ $+0.00100 \mathrm{X}_{1}^{*} \mathrm{X}_{2}$, with $\mathrm{R}^{2}=98.9 \%$. Where $\mathrm{Z}=$ titratable acidity, $\mathrm{X}_{1}$ = pod storage time, $X_{2}=$ drying time

From the model there was strong significant $(p \leq 0.001)$ influence of both the linear and quadratic factor of pod storage time on the model. There was significant $(p=0.016)$ influence of the linear factor of drying time on the model. The quadratic factor of drying time as well as the interactions factor had no significant influence on the model (Table 1). The model could explain 98.9\% of the variations in titratable acidity.

Response surface plot developed from the model (Figure 2) showed a slight curvilinear nature of the effect of pod storage time on titratable acidity, as pod storage duration increased, titratable acidity decreased drastically. The response surface plot also showed that drying time increases caused gradual decline in titratable acidity. The significant decrease in total acidity during pod storage is a very important phenomenon as it has great influence on the flavour development during processing [13].

The initial titratable acidity of the fresh non pod-stored beans after fermentation was $1.43 \mathrm{meq} / \mathrm{NaOH}$. After drying for six days the titratable acidity was 1.07 meq/ $\mathrm{NaOH}$. The initial titratable acidity of the pod stored beans after fermentation was $0.73,0.49$ and $0.27 \mathrm{meq} / \mathrm{NaOH}$ for the 7,14 and 21 days pod stored beans respectively. The results (Figure 2) indicated that titratable acidity decreased as drying time increased. It also shows that increasing pod storage durations decreased titratable acidity of the cocoa nib significantly after fermentation (Table 1).

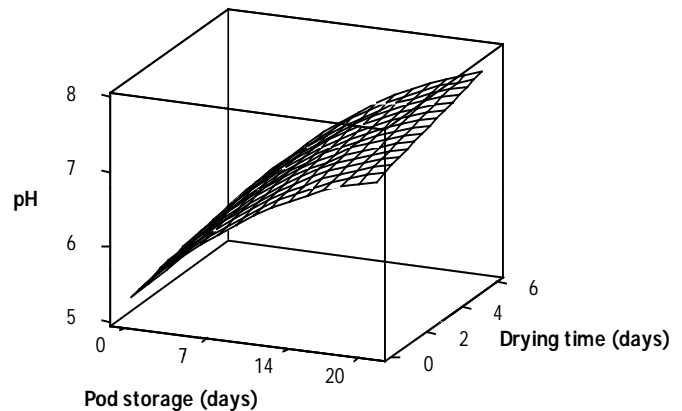

Figure 2: Response surface plot of titratable acidity of cocoa nib as a function of drying time and pod storage time.

The gradual decrease in total acidity during drying was due to loss of some of the volatile organic acids through the evaporating moisture from the beans [1]. These gradual changes are not so significant during the initial stages of drying as less moisture is lost in the bean but as the drying proceeds up to about 4-6 days there is significant decrease in total acidity due to the fact that by then more of the moisture and for that matter more of the volatile organic acids have been evaporated.

The decrease in acidity during the pod storage process was in line with similar findings by Faborode. They indicated that that there was great reduction in pulp volume during pod storage prior to fermentation which affects the production of acids by lactic acid bacteria, yeasts and acetic acid bacteria. Further research by [16] showed that under these conditions the development of lactic acid bacteria is suppressed and the respiration of sugars by yeasts is considerably increased over alcoholic fermentation and therefore nib acidification is greatly reduced.

\section{Effect of drying time and pod storage time on moisture of cocoa beans}

The recommended percentage moisture after drying has been established at $7.5 \%$ for secure storage of cocoa for a couple of months in the tropics. Above 8\% moisture there is the danger of moulds developing within the beans, whilst below $5 \%$ the beans are very brittle [5,22,23,28,29].

The initial moisture content of the fresh non-stored beans after fermentation was $55.31 \%$. After six days of drying the moisture content decreased to $8.94 \%$. The initial moisture of the pod stored beans were $50.58 \%, 35.02 \%$ and $26.58 \%$ for the 7 , 
14 and 21 days pod-stored beans respectively. The final moisture contents of the pod-stored beans after six days of drying were all lower than that of the non pod-stored beans as shown in Figure 3. The results indicated that the initial moisture in cocoa beans after fermentation decreases significantly (Table 1) with increasing pod storage.

The data obtained for the changes in moisture during drying and pulp pre-conditioning (pod storage) was fitted into a multiple regression model as follows;

$\mathrm{Z}=58.4508-1.3923 \mathrm{X}_{1}-11.7595 \mathrm{X}_{2}-0.0101 \mathrm{X}_{1}^{2}+0.5900 \mathrm{X}_{2}^{2}+$ $0.2235 X_{1}^{*} X_{2}$, with an $R^{2}=97.4 \%$. Where; $Z=$ moisture, $X_{1}=$ pod storage time, $\mathrm{X}_{2}=$ drying time

From the model there was significant influence of the linear factors of both drying time and pod storage time on moisture content of the beans (Table 1). The influence of drying time on moisture was more significant $(p<0.05)$ than that of pod storage time. Both drying and pod storage times had no significant quadratic effect on the model. The model could explain about $97.4 \%$ of the variations in moisture. Thus, only $2.6 \%$ of the variation was due to other factors not included in the model.

The rate of moisture loss as represented in Figure 3 shows clearly that the rate of moisture loss in the beans from the unstored pods was much steeper than those from the stored pods. This means that the rate of moisture loss during drying was greater for pods stored for 0 days. Also the actual amount of water lost in total after six days of drying was greater for pods stored for 0 days and decreased with increased days of pod storage. The crucial distinguishing factor is the initial moisture content available. The pod stored beans had lower initial moisture content and this where the effect of pod storage is relevant. The idea in cocoa drying is to reduce the moisture content quickly so as to reduce or eliminate the incidence of mould growth.

The model was used to generate response surface plot (Figure 3 ). The plot indicated a drastic decline in moisture content as the drying time increases. However, increasing the pod storage time resulted in a gradual decline in moisture content. There was significant $(\mathrm{p}<0.001)$ interaction effect of both the drying time and pod storage time on moisture changes, which means the effect of either of the factors on moisture loss depended on the levels of each factor.

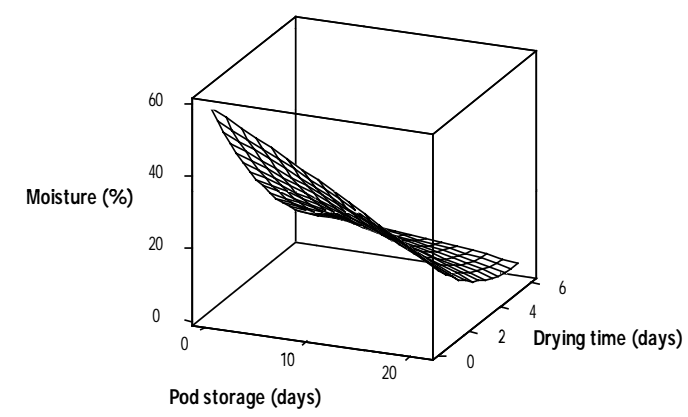

Figure 3: Response surface plot showing effect of pod storage and drying time on of moisture of cocoa beans.
Moisture loss during drying is a very important phenomenon in the primary processing of cocoa as it has great influence on the rate of Maillard browning reaction during subsequent roasting[30,31]. After six days of drying moisture content of the non pod stored beans was $8.94 \%$ which is above the recommended $7.5 \%$ indicating that six days of sun drying was not enough to reduce the moisture content of non pod stored beans to $7.5 \%$. The final moisture content of the 7, 14 and 21 days pod stored beans after six days of drying was 7.84\%, 6.34\% and $5.06 \%$ respectively indicating that after 7 days of pod storage beans moisture lost increases and that pod stored beans should not be dried beyond six days of sun drying.

\section{Effect of drying time and pod storage on total sugars content of cocoa nibs}

The level of total sugars in cocoa after drying is very important as it contributes to the amount of aroma substances formed during subsequent roasting. Reducing sugars, especially glucose are transformed during Maillard or caramelization reactions to Amadori compounds which undergo further transformations in subsequent reactions into colour and flavour development [13].

The data obtained for the changes in total sugars during drying of pulp preconditioned cocoa beans was fitted into a multiple regression model as follows;

$Z=97.0406-1.4671 X_{1}-10.4573 X_{2}-0.0091 X_{1}^{2}+0.3684 X_{2}^{2}$ $+0.0923 X_{1}^{*} X_{2}$ with $R^{2}=95 \%$. Where $Z=$ total sugars, $X_{1}=$ pod storage time, $\mathrm{X}_{2}=$ drying time

From the model, there was strong significant influence of the linear factor of drying time on the model. There was also slight significant $(p=0.05)$ influence of the linear factor of pod storage on the model. There was no significant influence of quadratic factors of both drying time and pod storage time on the model and the model could explain about $95.0 \%$ of the variations in total sugar content (Table 1). The response surface plots developed (Figure 4) showed a sharp linear decrease in total sugar as drying time increased. However, increasing the pod storage time showed a gradual decline in total sugar content.

The initial total sugar content of the fresh non pod stored beans after fermentation was $89.58 \mathrm{mg} / \mathrm{g}$. After six days of drying the total sugars content decreased to $44.28 \mathrm{mg} / \mathrm{g}$. The initial total sugars content of the pod stored beans after fermentation was $84.24,79.95$ and $65.10 \mathrm{mg} / \mathrm{g}$ for the 7,14 and 21 days respectively. The total sugar contents of the pod stored beans after six days of drying were all lower than that of the non pod stored beans as indicated in Figure 4.

The results indicated that the total sugars in cocoa beans decreases as it undergoes fermentation after pod storage. The participation of sugars in Maillard non enzymatic reactions to form flavour volatiles and colour pigments (Amadori intermediates) accounts for the reduction in total sugar content of cocoa nibs during drying. This is in line with the findings by [5] which indicated that decreases in the amount of total reducing sugars could reach $71 \%$ of the initial amount after 24 hours of oven drying at $40^{\circ} \mathrm{C}$ to $80^{\circ} \mathrm{C}$. 


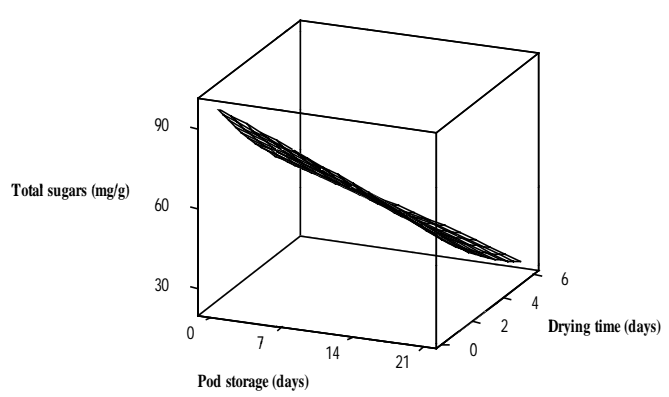

Figure 4: Response surface plot on effect of pod storage and drying time on total sugar of cocoa beans.

The reduction in total sugars after the fermentation of pod stored cocoa beans could be attributed to two possible causes, the first is the loss of sugars through respiration concomitantly with reduction of the pulp volume due to water evaporation and the second is the consumption of sugars through non enzymatic browning during fermentation of the beans $[14,16,19]$. Fermentation of pod stored beans was faster than in non pod stored beans. Therefore, six days of fermentation is more likely to cause over fermentation in pod stored beans than in non pod stored beans. Over fermentation is known to cause depletion of flavour volatile precursors such as sugars, amino acids and proteins [19,32-34].

\section{Effect of drying time and pod storage time on protein} content of cocoa nibs

The level of protein in cocoa after drying is very important as it contributes to the amount of aroma substance formed during subsequent roasting. Protein nitrogen, when broken down gets converted to peptide nitrogen and this is transformed during Maillard reactions to Amadori compounds [5,13,28] with resulting effects on flavour volatiles in cocoa beans.

The data obtained for the changes in percentage nitrogen during drying of pulp preconditioned cocoa beans was fitted into multiple regression models as follows;

$Z=7.06249-0.15641 X_{1}-1.07891 X_{2}+0.00047 X_{1}^{2}+0.07064 X_{2}^{2}$ $+0.01875 X_{1}^{*} X_{2}$, with $R^{2}=98.6 \%$. Where $Z=$ percentage nitrogen, $\mathrm{X}_{1}=$ pod storage time, $\mathrm{X}_{2}=$ drying time

The model indicated strong significant $(p<0.001)$ influence of the linear factor of both drying time and pod storage on the model. There was also significant $(\mathrm{p}<0.001)$ influence of the quadratic factor of drying time on the model. There was no significant influence of quadratic factors of pod storage time on the model and the model could explain about $98.6 \%$ of the variations in nitrogen (Table 1). The response surface plots developed from the model (Figure 5) showed a drastic decrease in nitrogen as drying time increased.

\section{Effect of drying time and pod storage time on percentage free fatty acids}

Free fatty acids (FFA) are carboxylic acids released from triglycerides through the effect of a lipase [34]. Higher FFA content leads to quality reduction in fermented cocoa beans as well as decrease in hardness of cocoa butter [35] and must be considered as a raw cocoa commercial value reducing factor both for producers and chocolate manufacturers. For reasons of quality therefore, the directive 73/241/EEC (EEC, 1973) limits the maximum FFA content to $1.75 \%$ oleic acid equivalent in cocoa butter [34].

The data obtained for the changes in percentage free fatty acids during drying of pulp preconditioned cocoa beans was fitted into multiple regression models as follows;

$\mathrm{Z}=0.890600+0.026541 \mathrm{X}_{1}+0.002331 \mathrm{X}_{2}-0.000032 \mathrm{X}_{1}^{2}$ $+0.009453 \mathrm{X}_{2}^{2}+0.004275 \mathrm{X}_{1}^{*} \mathrm{X}_{2}$ with $\mathrm{R}^{2}=90.7 \%$. Where $\mathrm{Z}=$ percentage free fatty acid, $X_{1}=$ pod storage time, $X_{2}=$ drying time

The model showed that at $95 \%$ confidence level, there was no significant influence of both the drying time and pod storage on free fatty acid in cocoa nibs (Table 1). The response surface plots developed from the model (Figure 6) showed that the effect of either pod storage or drying time on rise in free fatty acids depends on the levels of either of the factors.

The initial FFA of the fresh non-stored beans after fermentation was $0.87 \%$. After six days of drying the $\%$ FFA content increased to $1.18 \%$. The initial \%FFA of the 7, 14 and 21 days pod stored beans after fermentation was $1.04 \%, 1.21 \%$ and $1.45 \%$ respectively. The results obtained (Figure 6) indicated significant increases in the \%FFA content as pod storage duration increases. This result is contrary to findings by [33] who concluded that pod storage had no significant effect on \%FFA. However, their work was

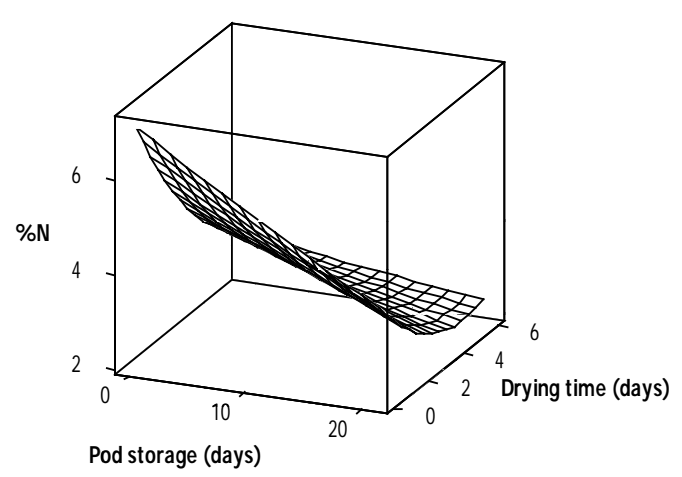

Figure 5: Response surface plot of protein content of cocoa nib as influenced by drying time and pod storage.

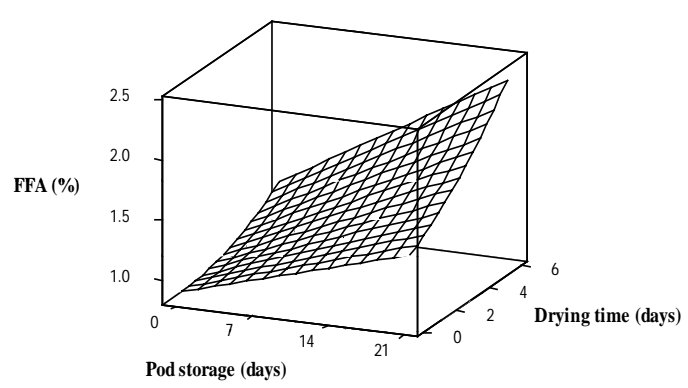

Figure 6: Response surface plot of effect of drying time and pod storage on FFA of cocoa nibs. 
restricted to 9 days of pod storage and did not include six days of fermentation. The formation of FFA in raw cocoa beans has been attributed to the activity of the lipase enzymes from moulds and beans. Other factors such as over fermentation, storage period, water activity and bean germination have been found to favour lipase activity in raw cocoa beans [33-36].

Cocoa butter naturally contains about $1.08 \%$ FFA Six days of slow sun drying provided enough time for significant lipase enzyme activity to considerably increase the FFA. Six days of fermentation after pod storage is likely to cause over fermentation [16] which allows enough time for lipase producing moulds such as $R$. oryzae and A. corymbifera to multiply and produce lipase to cause changes in the beans [33].

The EEC, 1973 limits the concentration of FFA in cocoa nibs to $1.75 \%$ [33]. FFA values of $1.80 \%$ and $2.55 \%$ were recorded in the nibs from the 14 and 21days pod stored beans respectively after six days of drying time. Mould growth and percent germination were found to be very high in the 14 and 21 days pod stored beans [11]. The increase in free fatty acids as pod storage time and drying time increases is rather due to mould growth, over fermentation and germination which resulted from pod storage periods beyond seven days $[33,36]$.

\section{Conclusion}

Both pod storage and drying influenced to varying levels the nib acidification, flavour precursors (protein nitrogen and total sugars) and FFA levels in fermented cocoa beans. Increasing pod storage consistently decreased the moisture content, non-volatile acidity, protein nitrogen and total sugars with concomitant increases in $\mathrm{pH}$ and FFAs during drying of the fermented beans. Drying had minimal effect on protein nitrogen and total sugars but drastically decreased moisture content of beans while $\mathrm{pH}$ and FFA of the fermented beans increased consistently at all levels of pod storage. The beans from the pods stored for more than 10 days had FFA levels exceeding $1.75 \%$ after drying. This suggests that to obtain well fermented cocoa beans with acceptable FFA levels, cocoa pods should not be stored for more than 10 days after harvesting. Thus, both pod storage and drying influenced the souring or nib acidification process $(\mathrm{pH}$ and non-volatile acidity), flavour precursors development (sugars degeneration and protein degradation) and FFA levels in fermented cocoa beans. However, the rates of change in souring, sugars degeneration, protein degradation and FFA concentrations were more dependent on pod storage than on drying.

\section{Acknowledgment}

The authors are thankful to the Cocoa Research Institute of Ghana, Tafo, Eastern Region, Ghana for providing the cocoa pods samples and technical support.

\section{References}

1. Fowler MS (2009) Cocoa beans: From Tree to Factory. In: Industrial Chocolate manufacture and use. Fourth Edition. Beckett ST (eds) WileyBlackwell Science Oxford, UK, pp: 137-152.

2. Afoakwa E O (2010) Chocolate Science and Technology. Wiley-Blackwell Publishers Oxford UK 3-22.
3. Afoakwa EO, Quao J, Budu AS, Takrama J, Saalia FK (2013a) Effects of pulp preconditioning on total polyphenols, o-diphenols and anthocyanin concentrations during fermentation and drying of cocoa (Theobroma cacao) beans. Int J Food Sci Nutr 3(2013): 235-245.

4. Hansen CE del Olmo M, Burri C (1998) Enzyme activities in cocoa beans during fermentation. J Sci Food Agri 77: 273-281.

5. Hashim P, Jinap S, Mohammad SKS, Ali A (1998) Changes in free amino acid, peptide-N, Sugar and pyrazine concentration during cocoa fermentation. Journal of the Science of Food and Agriculture 78(4): 535550 .

6. Thompson SS, Miller KB, Lopez AS (2007) Cocoa and coffee. In: Doyle MP, Beuchat LR, Montville TJ (Eds.), Food Microbiology Fundamentals and Frontiers. ASM Press, Washington, DC, pp. 837-850.

7. Afoakwa EO, Paterson A (2010) Cocoa Fermentation: Chocolate Flavour Quality. In: Encyclopedia of Biotechnology in Agriculture and Food. Taylor \& Francis Publishing Inc, Oxford, U.K, pp. 457 - 468.

8. Owusu M, Petersen MA, Heimdal H(2012) Effect of fermentation method, roasting and conching condition on the aroma volatiles of dark chocolate. Journal of Food Processing and Preservation 36(5): 446-456.

9. Schwan RF, Rose, Board (1995) Microbial fermentation of cocoa beans, with emphasis on enzymatic degradation of the pulp. J Applied Bacteriology 79: 96S-107.

10. Schwan RF, Wheals A E (2004) The microbiology of cocoa fermentation and its role in chocolate quality. Crit Rev Food Sci Nutr 44(4): 205 -221.

11. Afoakwa EO, Quao J, Budu AS, Takrama J, Saalia FK (2011) Effect of pulp pre-conditioning on acidification, proteolysis, sugars and free fatty acids concentration during fermentation of cocoa (Theobroma cacao) beans. Int J Food Sci Nutr 62(7): 755- 764.

12. Senenayake M, Jansz ER, Buckle K A (1995) Effect of variety and location on optimum fermentation requirements of cocoa beans: an aid to fermentation on a cottage scale. Journal of the Science of Food and Agriculture 69(4): 461-465.

13. Afoakwa EO, Paterson A, Fowler M, Ryan A (2008) Flavour formation and character in cocoa and chocolate: a critical review. Crit Rev Food Sci Nutr 48(9): 840-857.

14. Afoakwa EO, Kongor J E, Takrama JF, Budu AS (2013b) Changes in acidification, sugars and mineral composition of cocoa pulp during fermentation of pulp pre-conditioned cocoa (Theobroma cacao) beans. Int J Food Sci Nutr 20(3): 1215-1222.

15. Biehl B, Meyer B, Crone G, Pollmann L, Said MB (1989) Chemical and physical changes in the pulp during ripening and post-harvest storage of cocoa pods. Journal of the Science of Food and Agriculture, 48(2): 189-208.

16. Biehl B, Meyer B, Said MB, Samarakoddy RJ (1990) Bean spreading: a method for pulp preconditioning to impair strong nib acidification during cocoa fermentation in Malaysia. Journal of the Science of Food and Agriculture 51(1): 35-45.

17. Voigt J, Biehl B, Heinrichs H, Kamaruddin S, Gaim MG, et al. (1994) In-vitro formation of cocoa-specific aroma precursors: aroma-related peptides generated from cocoa seed protein by co-operation of an aspartic endoproteinase and a carboxy-peptidase. Food Chemistry 49(2): 173-180.

18. Afoakwa EO, Kongor JE, Takrama JF, Budu AS (2013c) Changes in nib acidification and biochemical composition during fermentation of pulp pre-conditioned cocoa (Theobroma cacao) beans. International Food Research Journal 20(4): 1843-1853.

19. Meyer B, Biehl B, Said, Samarakoddy, RJ (1989) Postharvest pod storage: 
a method for pulp preconditioning to impair strong nib acidification during cocoa fermentation in Malaysia. Journal of the Science of Food and Agriculture 48(3): 285-304.

20. Nazaruddin R, Seng LK, Hassan O, Said M (2006) Effect of pulp preconditioning on the content of polyphenols in cocoa beans (Theobroma cacao) during fermentation. Industrial Crops and Production 24(1): 87-94.

21. Afoakwa E0, Quao J, Budu, Takrama AS, Saalia (2012) Influence of pulp pre-conditioning on fermentative quality in Ghanaian cocoa (Theobroma cacao) beans. International Food Research Journal 19: 59-66.

22. Cunha J D (1990) Performance of Burairo $33^{\star 3 m}$ dryer for cocoa. Agrotropica 2 (3): 157-160.25.

23. Faborode MO, Favier JF, Ajayi OA (1995) On the effects of forced air drying on cocoa quality. Journal of Food Engineering 25(4): 455-472.

24.AOAC (2005) Official Methods of Analysis. (18 ${ }^{\text {th }}$ edn) Association of Official Analytical Chemists. Washington DC, USA.

25. Dubois M, Gilles KA, Hamilton JK, Rebers PA, Smith F (1956) Colorimetric method for the determination of sugars and related substances. Analytical Chemistry 28(3) 350-356.

26.IOCCC (International Office of Cocoa, Chocolate and Sugar Confectionery) (1996) Determination of free fatty acids (FFA) content of cocoa fat as a measure of cocoa nib acidity. Analytical Method 421993.

27. Beckett ST (2009) Industrial Chocolate Manufacture and Use, $2^{\text {nd }}$ edn) Blackie Academic and Professional, Glasgow, UK.

28. Galvez SL, Loiseau G, Paredes JL, Barel M, Guiraud JP (2007) Study on the microflora and biochemistry of cocoa fermentation in the Dominican
Republic. Int J Food Microbiol 114(1): 124-130.

29. Ndukwu MC (2009) Effect of Drying Temperature and Drying Air Velocity on the Drying Rate and Drying Constant of Cocoa Bean. Agricultural Engineering International: CIGR Journal (11) : 203-213.

30. Belitz HD, Grosch W (1999) Food Chemistry. (2 ${ }^{\text {nd }}$ edn) Springer Verlag, Berlin, Germany.

31. ADM Cocoa (2008) The De Zaan Cocoa Manual. Archer Daniels Midland Company BV, the Netherlands.

32. Biehl, B, Brunner, Passern E, Quesnel D, Victor C, et al. (1985) Acidification, proteolysis and flavour potential in fermenting cocoa beans. Journal of the Science of Food and Agriculture 36(7): 583-598.

33. Guehi TS, Dingkuhn M, Cros E, Fourny G, Ratomahenina et al. (2007) Identification and lipase-producing abilities of moulds isolated from Ivorian raw cocoa beans. Journal of Agriculture and Biological Sciences 3(6): 838-843.

34. Guehi T S, Yao DN, Manizan NP, Nevry KR, Koffi LB, et al. (2008) Comparison of the degree of fermentation and fungal profiles of raw cocoa beans sourced from three Ivorian main producing regions. African Journal of Food Science 2(10):112-118.

35. Pontillon CJ (1998) The cocoa butter and the fat in chocolate. In: Pontillon CJ (Ed.), Cocoa, Chocolate, Production, Use and Characteristics, Techniques and documentation, Paris. France: pp. 326-392.

36. Guehi TS (2003) Study of the origin and conditions of operation of the lipase activity involved in the action of the free fatty acids in cocoa. Ph.D. Thesis, University of Science and Technology, Montpellier 2, France. 